\title{
Pemetaan Tingkat Salinitas (Daya Hantar Listrik) Pada Lahan Sawah Tadah Hujan di Desa Durian, Kecamatan Pantai Labu, Kabupaten Deli Serdang
}

Salinity Rate Mapping (Electrical Conductivity) In Rainfed Rice Fields In Durian Village, District of Pantai Labu, Deli Serdang

\section{Muhammad Ridho Catur Prasetya, Razali*, Sarifuddin}

Program Studi Agroteknologi, Fakultas Pertanian, USU, Medan 20155

*Corresponding author: razali_07@yahoo.com

\section{ABSTRACT}

The aim of this research is to get salinity and distribution data on rainfed field through survey activity in Durian Village, District of Pantai Labu, Deli Serdang Regency and Geographical Information System Laboratory and Soil Chemistry and Soil Fertility Faculty of Agriculture University of Sumatera Utara. Held in September to October 2017. S The research was conducted by Free Grid Survey method with density level of 1 sample per 25 ha. Observation parameters Ground salinity (Electrical Conductivity), Na-dd (Spektro Flamefotometer) and soil $\mathrm{pH}$ (Potentiometric Electrode). Data analysis using Interpolation method. The analysis showed that the distribution of soil salinity has two criteria according to Dobberman and Fairhurst (2000) that is high criterion with area of 625 ha (83,4\%) and medium criteria with 125 ha (16,6\%). Measurements of $\mathrm{pH}$ and $\mathrm{Na}$-dd values were performed after salinity was found on the land. The soil and Na-dd soil pH values in rainfed lowland rice field had a soil pH of 4.7 and low Na-dd value with a mean of 0.15 me / 100, so that the land can be classified into the saline soil.

Keywords: Salinity, $\mathrm{pH}, \mathrm{Na}-\mathrm{dd}$, Interpolation.

\begin{abstract}
ABSTRAK
Penelitian ini bertujuan untuk mendapatkan data tingkat salinitas dan penyebaran pada lahan sawah tadah hujan melalui kegiatan survey di Desa Durian, Kecamatan Pantai Labu, Kabupaten Deli Serdang serta di Laboratorium Sistem Informasi Geografis dan Laboratorium Kimia dan Kesuburan Tanah Fakultas Pertanian Universitas Sumatera Utara. Dilaksanakan pada bulan September sampai dengan Oktober 2017. Penelitian dilakukan dengan metode Survei Grid Bebas dengan tingkat kerapatan 1 sampel tiap 25 ha. Parameter pengamatan Salinitas tanah (Electrical Conductivity), Na-dd (Spektro Flamefotometer) dan $\mathrm{pH}$ tanah (Elektroda Potensiometri). Analisis data menggunakan metode Interpolasi. Hasil analisis menunjukkan bahwa penyebaran salinitas tanah memiliki dua kriteria menurut Dobberman dan Fairhurst (2000) yaitu kriteria tinggi dengan luasan 625 ha ( 83,4\% ) dan kriteria agak tinggi dengan luasan 125 ha (16,6 \% ). Setelah diketahui kadar salinitas pada lahan tersebut, pengukuran nilai $\mathrm{pH}$ dan $\mathrm{Na}$-dd dilakukan. Nilai $\mathrm{pH}$ tanah dan Na-dd pada lahan sawah tadah hujan memiliki $\mathrm{pH}$ tanah masam dengan rataan 4.7 dan Nilai Na-dd yang rendah dengan rataan 0,15 me/100, sehingga tanah tersebut dapat diklasifikasikan menjadi tanah Salin.
\end{abstract}

Kata kunci : Salinitas, pH, Na-dd, Interpolasi. 


\section{PENDAHULUAN}

Selama periode lima tahun terakhir, produktivitas padi di Indonesia mengalami peningkatan pertumbuhan yang lebih rendah yaitu sebesar $1,33 \%$ per tahun atau sebesar 51,36 Kwintal per hektar di tahun 2012 menjadi 52,05 Kwintal per hektar di tahun 2016 (Pusat Data dan Sistem Informasi Pertanian, 2016).

Desa Durian merupakan desa yang berada di Kecamatan Pantai Labu Kabupaten Deli Serdang, memiliki luas $1200 \mathrm{Ha}$ dengan komoditi padi sawah dengan luas lahan sawah 750 Ha. Produksi padi sawah di Desa Durian masih memberikan hasil yang tergolong rendah, umumnya rata-rata produksi 3 - 4,5 ton/Ha dan masih di bawah rata-rata produktivitas nasional sebesar $(52,05 \mathrm{Kwintal} / \mathrm{Ha})$ atau 5,2 ton/ $\mathrm{Ha}$ (Badan Pusat Statistik Sumatera Utara, 2016).

Berdasarkan wawancara dengan beberapa petani di Desa Durian Kecamatan Pantai Labu, terdapat beberapa masalah yang menyebabkan rendahnya produksi padi sawah di daerah ini salah satunya adalah salinitas tinggi karna termasuk wilayah pesisir yang sebagian besar tanahnya mengandung kandungan garam cukup tinggi akibat pengaruh pasang surut air laut, disamping masalah pengairan karena berupa lahan sawah tadah hujan.

Cekaman salinitas merupakan cekaman abiotik yang dapat mempengaruhi produktivitas dan kualitas tanaman. pertumbuhan akar, batang dan luas daun berkurang karena ketidak seimbangan metabolik yang disebabkan oleh keracunan ion $\mathrm{NaCl}$, cekaman osmotik dan kekurangan hara (Sembiring dan Gani, 2010).

Menurut Boiran (2004) perkembangan lanjut tanah yang dipengaruhi oleh kadar garam terutama $\mathrm{NaCl}$ memperberat kerusakan tanah karena tanah yang demikian tidak dapat lagi dibudidayakan dengan tanaman yang peka terhadap tingginya salinitas tanah. Usaha desalinasi tanah juga sangat mahal karena memerlukan bahan amelioran dan pencucian garam yang terdapat dalam tanah.
Produksi padi sawah akibat cekaman salinitas dapat menyebabkan penurunan produksi. Produksi padi sawah varietas Ciherang yang ditanam dilahan salin berkisar 2-3 ton per hektar, padahal varietas Ciherang memiliki potensi hasil 8,5 ton/ha dengan hasil rata-rata 6,0 ton/ha pada tanah non salin, hal ini menunjukkan bahwa faktor salinitas tanah menjadi penghambat peningkatan produksi padi (Hutajulu, dkk., 2013).

Berdasarkan penjelasan diatas maka diperlukan penelitian untuk melakukan survey dan pemetaan tingkat salinitas (DHL) dan penyebaran nya pada lahan sawah tadah hujan di Desa Durian, Kecamatan Pantai Labu, Kabupaten Deli Serdang.

\section{BAHAN DAN METODE}

Waktu penelitian dimulai pada bulan September 2017. Penelitian ini dilaksanakan di Desa Durian Kecamatan Pantai Labu Kabupaten Deli Serdang yang memiliki luas $1200 \mathrm{Ha}$, dan luas lahan sawah tadah hujannya 750 Ha. Secara geografis lokasi ini terletak pada $03^{\circ} 37^{\prime} 50^{\prime \prime}-03^{\circ} 40^{\prime} 30^{\prime}$ 'LU dan $98^{\circ} 50^{\prime} 10^{\prime \prime}-98^{\circ} 52^{\prime} 10^{\prime \prime}$ ' BT.

Bahan yang digunakan dalam penelitian ini adalah peta lokasi penelitian skala $1: 50.000$, sampel tanah yang diambil dari daerah penelitian, serta bahan - bahan kimia untuk analisis tanah, alat yang digunakan dalam penelitian ini adalah GPS (Global Positioning System), bor tanah, cangkul, kantong plastik berkapasitas $1 \mathrm{~kg}$, kertas label, alat tulis, karet gelang, serta alatalat laboratorium yang mendukung dalam penelitian ini.

Penelitian ini menggunakan metode yang Survey Grid Bebas dengan tingkat survey semi detail (kerapatan pengamatan 1 sampel setiap 25 ha).

Parameter yang diamati meliputi Daya Hantar Listrik tanah (mmhos/cm) dengan menggunakan metode Electrical Conductivity (EC), Na-dd tanah dengan menggunakan metode Spektro 
Flamefotometer, $\mathrm{pH}$ tanah dengan menggunakan metode Elektroda
Data hasil analisis laboratorium yang diperoleh dianalisis dengan menggunakan analisis spasial menggunakan software QGIS

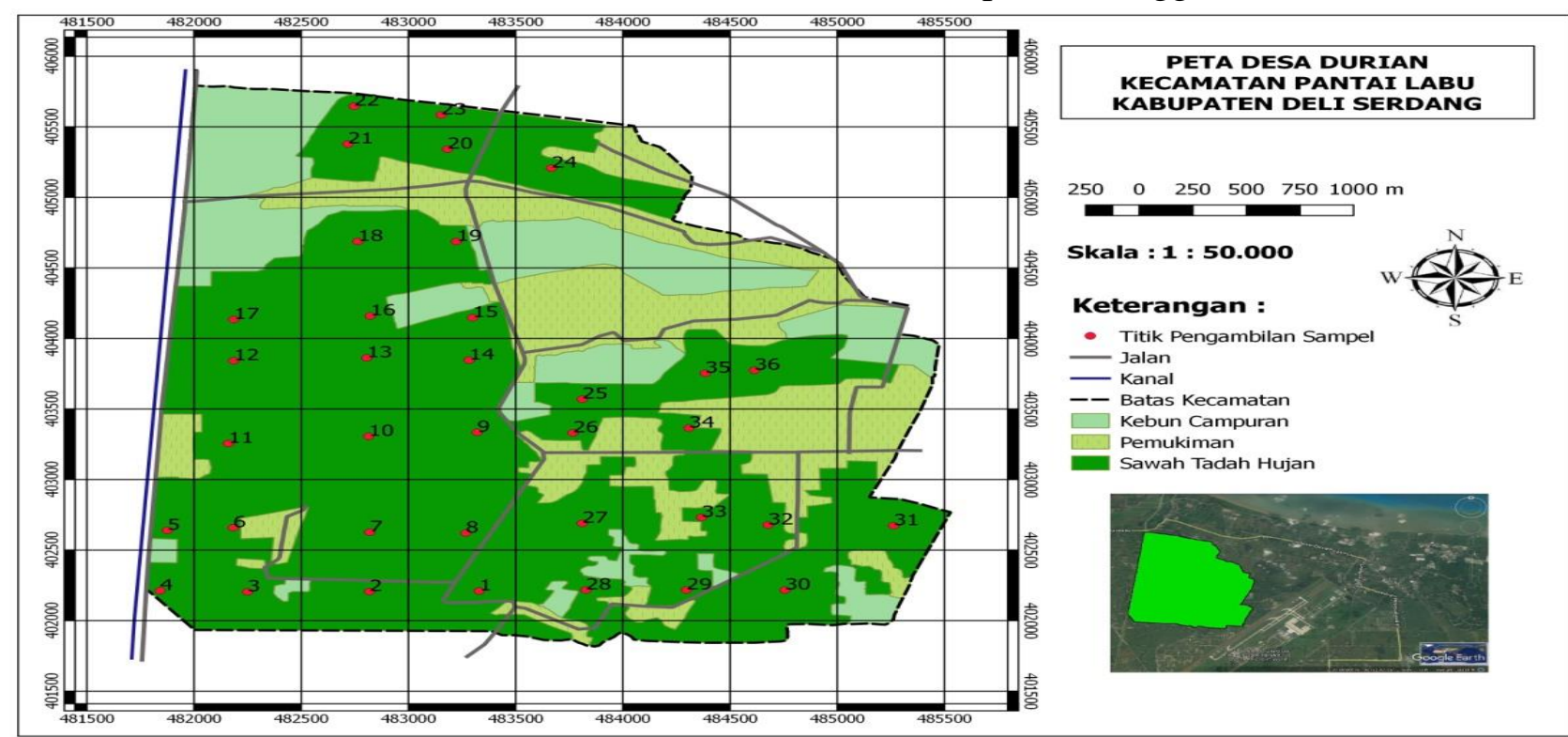

Gambar 1. Peta Pengambilan Titik Sampel Desa Durian Kecamatan Pantai Labu, Kabupaten Deli Serdang

2.18 (Quantum Geografic Information System) dengan teknik interpolasi. Out put analisis spasial adalah cluster tingkat/kriteria DHL (mmhos/cm). Setelah diperoleh data

\section{HASIL PENELITIAN}

\section{Kondisi Wilayah}

Desa Durian termasuk pada Kecamatan Pantai Labu, Kabupaten Deli Serdang, Provinsi Sumatera Utara. Daerah ini terletak di dataran rendah dengan ketinggian tempat 2-7 meter di atas permukaan laut $(d p l)$, dengan luas daerah $1200 \mathrm{Ha}$.

Sebelah Utara : Berbatasan dengan Desa Batang Biara Kecamatan Pantai Labu. kemudian dilakukan analisis $\mathrm{pH}$ dan $\mathrm{Na}$-dd berdasarkan kriteria DHL tanaman padi menurut Dobberman dan Fairhurst (2000).

Sebelah Selatan : Berbatasan dengan Desa Rumbia dan Desa Sidourip Kecamatan Beringin.

Sebelah Timur : Berbatasan dengan Desa Ramunia Kecamatan Beringin.

Sebelah Barat : Berbataasan dengan Desa Kampung Dalam Kecamatan Batang Kuis.

Dari hasil penelitian yang dilakukan diperoleh bahwa penggunaan lahan di Desa Durian didominasi oleh lahan sawah tadah hujan seluas $750 \mathrm{Ha}(62,50 \%$,) dan sisanya merupakan kebun campuran seluas $194 \mathrm{Ha}$ $(16,17 \%)$ dan pemukiman seluas $256 \mathrm{Ha}$ $(21,33 \%)$. 
Tabel 1. Penggunan Lahan di Desa Durian Kecamatan Pantai Labu Kabupaten Deli Serdang

\begin{tabular}{lcc}
\hline Penggunaan Lahan & Luas (Ha) & Persentase (\%) \\
\hline Sawah Tadah Hujan & 750 & 62,50 \\
\hline $\begin{array}{l}\text { Kebun Campuran } \\
\text { (Kelapa, Kelapa }\end{array}$ & 194 & 16,17 \\
Sawit, Pinang) & & 21,33 \\
\hline Pemukiman & 256 & $\mathbf{1 0 0}$ \\
\hline Total & $\mathbf{1 2 0 0}$ & \\
\hline
\end{tabular}

\section{Kandungan Salinitas Tanah Pada Lahan Sawah}

Tabel 2. Kandungan Salinitas Tanah Pada Lahan Sawah

\begin{tabular}{|c|c|c|c|}
\hline $\begin{array}{l}\text { Nomor } \\
\text { Sampel }\end{array}$ & $\begin{array}{c}\text { DHL } \\
(\mathrm{mmhos} / \mathrm{cm})\end{array}$ & Kriteria $1 *$ & Kriteria $2 * *$ \\
\hline 1 & 4.05 & Tinggi & Tinggi \\
\hline 2 & 4.12 & Tinggi & Tinggi \\
\hline 3 & 4.23 & Tinggi & Tinggi \\
\hline 4 & 4.44 & Tinggi & Tinggi \\
\hline 5 & 4.55 & Tinggi & Tinggi \\
\hline 6 & 4.28 & Tinggi & Tinggi \\
\hline 7 & 4.22 & Tinggi & Tinggi \\
\hline 8 & 4.15 & Tinggi & Tinggi \\
\hline 9 & 4.17 & Tinggi & Tinggi \\
\hline 10 & 4.22 & Tinggi & Tinggi \\
\hline 11 & 4.22 & Tinggi & Tinggi \\
\hline 12 & 4.27 & Tinggi & Tinggi \\
\hline 13 & 4.23 & Tinggi & Tinggi \\
\hline 14 & 4.20 & Tinggi & Tinggi \\
\hline 15 & 4.25 & Tinggi & Tinggi \\
\hline 16 & 4.25 & Tinggi & Tinggi \\
\hline 17 & 4.29 & Tinggi & Tinggi \\
\hline 18 & 4.28 & Tinggi & Tinggi \\
\hline 19 & 4.26 & Tinggi & Tinggi \\
\hline 20 & 4.29 & Tinggi & Tinggi \\
\hline 21 & 4.39 & Tinggi & Tinggi \\
\hline 22 & 4.42 & Tinggi & Tinggi \\
\hline 23 & 4.33 & Tinggi & Tinggi \\
\hline 24 & 4.28 & Tinggi & Tinggi \\
\hline 25 & 4.18 & Tinggi & Tinggi \\
\hline 26 & 4.19 & Tinggi & Tinggi \\
\hline 27 & 4.11 & Tinggi & Tinggi \\
\hline 28 & 4.06 & Tinggi & Tinggi \\
\hline 29 & 3.82 & Tinggi & Agak Tinggi \\
\hline 30 & 3.77 & Tinggi & Agak Tinggi \\
\hline 31 & 3.85 & Tinggi & Agak Tinggi \\
\hline 32 & 3.85 & Tinggi & Agak Tinggi \\
\hline 33 & 3.91 & Tinggi & Agak Tinggi \\
\hline
\end{tabular}




\begin{tabular}{cccc}
\hline 34 & 4.04 & Tinggi & Tinggi \\
35 & 4.12 & Tinggi & Tinggi \\
36 & 4.18 & Tinggi & Tinggi \\
\hline Total Rataan & $\mathbf{4 . 1 6}$ & Tinggi & Tinggi \\
\hline
\end{tabular}

Keterangan : * Menurut Staf Pusat Penelitian Tanah (1983), ** Menurut Dobberman dan Fairhurst (2000)

Penyebaran tingkat salinitas pada lahan sawah tadah hujan memiliki perbedaan tingkat salinitasnya, pada lahan sawah tadah hujan tersebut memiliki kriteria yang digolongkan berdasarkan kriteria Dobberman dan Fairhurst (2000) yaitu kriteria tinggi denga luasan 625 ha $(83,4 \%)$ dan kriteria agak tinggi dengan luasan 125 ha ( $16,6 \%$ ). Keadaan ini dapat menyebabkan terjadinya penurunan produksi akibat cekaman salinitas yang tinggi, sehingga menyebab kan pertumbuhan tanaman terganggu. Hal ini sesuai dengan Subagyono (2008) yang menyatakan bahwa, salinitas menekan proses pertumbuhan tanaman dengan efek yang menghambat pembesaran dan pembelahan sel, produksi protein serta penambahan biomassa tanaman. Tanaman yang mengalami stress garam umumnya tidak menunjukkan respon dalam bentuk kerusakan langsung tetapi pertumbuhan yang tertekan dan perubahan secara perlahan.

Berdasarkan hasil analisis salinitas tanah pada Tabel 2 diketahui penyebaran tingkat salinitas tanah tinggi, sehingga diperlukan penggunaan varietas tanaman padi yang toleran terhadap salinitas dan pemberian bahan amelioran untuk memperbaiki sifat fisik dan kimia tanah. Bahan amelioran dapat berupa kapur atau dolomit, dan juga bahan organik tanah. Hal ini sesuai dengan Susanto, dkk., (1997) yang menyatakan bahwa bahan amelioran yang sering digunakan dalam budidaya padi adalah dolomit. Dolomit selain mengandung unsur $\mathrm{Ca}(32.0 \%)$ juga mengandung $\mathrm{Mg}(4.03 \%)$. Pemberian kapur di lahan salinitas dapat memperbaiki (1) sifat fisik tanah, yaitu memperbaiki granulasi tanah, sehingga aerasi lebih baik, (2) sifat kimia tanah, yaitu menurunkan kepekatan ion $\mathrm{H}$, menurunkan kelarutan $\mathrm{Fe}$, $\mathrm{Al}$ dan $\mathrm{Mn}$, meningkatkan ketersediaan $\mathrm{Ca}$, $\mathrm{Mg}, \mathrm{P}$ dan Mo serta meningkatan kejenuhan basa, (3) sifat biologi tanah, yaitu meningkatkan kegiatan jasad renik tanah. Selain kapur, bahan organik juga berpengaruh cukup baik untuk meningkatkan kesuburan lahan salin. Pemberian bahan organik pada tanah-tanah salin dapat memperbaiki: (1) sifat fisik tanah, tanah menjadi gembur dan aerasi tanah lebih baik, (2) sifat kimia tanah, yaitu meningkatnya kapasitas tukar kation (KTK) dan meningkatnya ketersediaan hara, (3) sifat biologi tanah, yaitu meningkatnya populasi mikroorganisme tanah.

Dari hasil penelitian diketahui nilai terendah salinitas tanah terdapat pada sampel 30 yaitu $3.77 \mathrm{mmhos} / \mathrm{cm}$ dan nilai tertinggi pada sampel 5 yaitu $4.55 \mathrm{mmhos} / \mathrm{cm}$. Total nilai rataan salinitas tanah pada lahan sawah tadah hujan yaitu $4.16 \mathrm{mmhos} / \mathrm{cm}$. Menurut Staf Pusat Penelitian Tanah (1983) serta Dobberman dan Fairhurst (2000) dapat digolongkan status salinitas tanah pada lahan sawah tadah hujan tersebut tinggi. Tingkat salinitas yang semakin dekat dengan kanal dan aut maka nilai nya akan semakin tinggi, dan semakin menjauhi kanal dan laut akan semakin rendah. Pola penyebarannya dapat dilihat pada Gambar 2: 


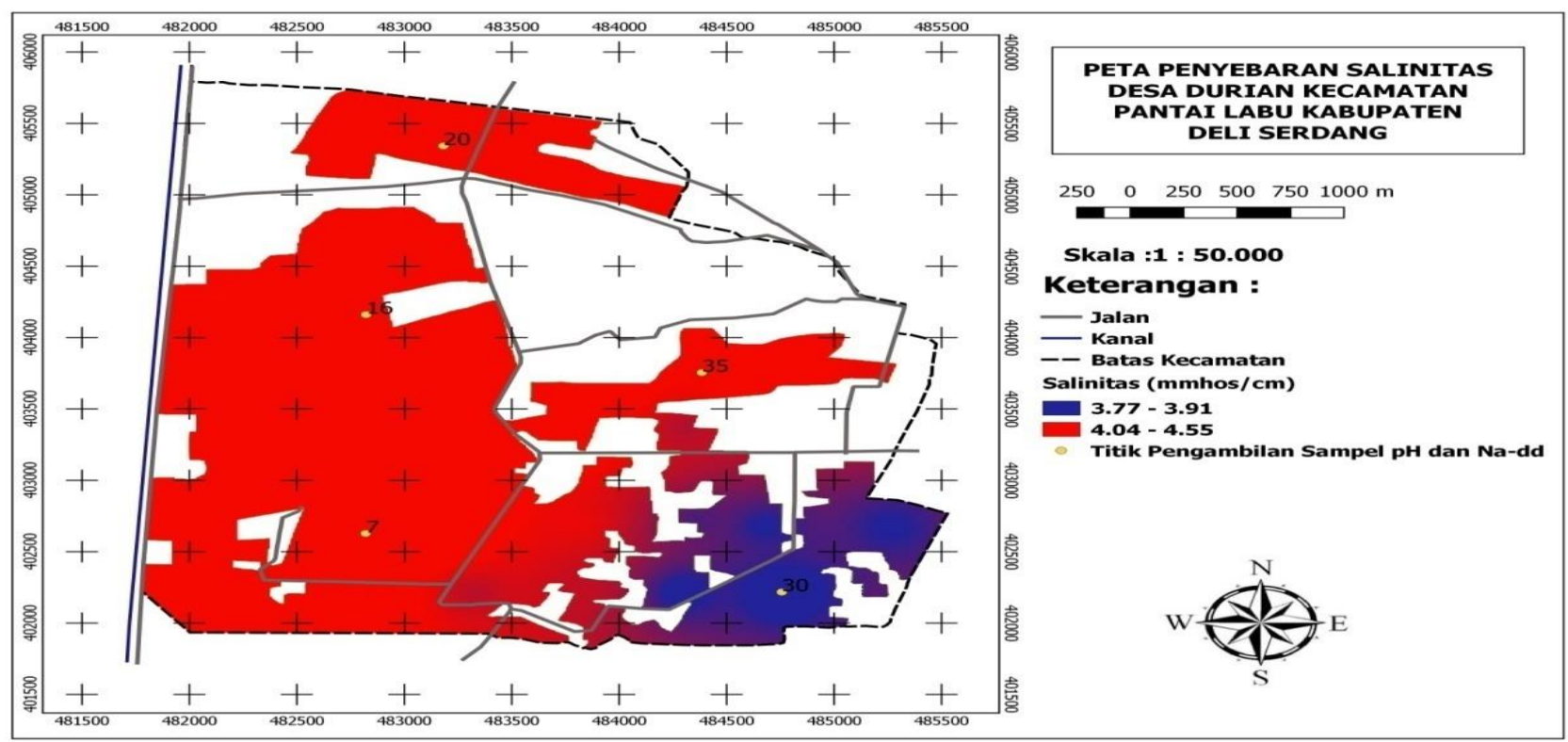

Gambar 2. Peta Pola Penyebaran Salinitas di Lahan Sawah Tadah Hujan

\section{Nilai pH Tanah dan Na-dd Pada Lahan Sawah Tadah Hujan}

Tabel 3. Hasil Analisis pH Tanah

\begin{tabular}{ccc}
\hline Nomor Sampel & pH H2O & Kriteria* \\
\hline 7 & 4.7 & Masam \\
16 & 4.8 & Masam \\
20 & 4.5 & Masam \\
30 & 4.7 & Masam \\
35 & 4.8 & Masam \\
\hline Total Rataan & $\mathbf{4 . 7}$ & Masam \\
\hline
\end{tabular}

Keterangan : * Menurut Staf Pusat Penelitian Tanah (1983)

Tabel 4. Hasil Analisis Na-dd Tanah

\begin{tabular}{ccc}
\hline Nomor Sampel & Na-dd $(\mathbf{m e} / \mathbf{1 0 0})$ & Kriteria* $^{*}$ \\
\hline 7 & 0.14 & Rendah \\
16 & 0.17 & Rendah \\
20 & 0.15 & Rendah \\
30 & 0.14 & Rendah \\
35 & 0.15 & Rendah \\
\hline Total Rataan & $\mathbf{0 . 1 5}$ & Rendah \\
\hline
\end{tabular}

Keterangan : * Menurut Staf Pusat Penelitian Tanah (1983)

Dari hasil pengambilan contoh tanah lahan sawah tadah hujan di Desa Durian Kecamatan Pantai Labu, Kabupaten Deli Serdang diperoleh 5 contoh tanah komposit, pengkompositan tanah dilakukan untuk mewakili seluruh sampel tanah. Pengambilan contoh tanah berdasarkan kriteria salinitas Dobberman dan Fairhurts (2000) yaitu kriteria 2- $4 \mathrm{mmhos} / \mathrm{cm}$ dan $4-6 \mathrm{mmhos} / \mathrm{cm}$. Titik sampel tanah $\mathrm{pH}$ dapat dilihat pada Gambar 2, hasil analisis contoh tanah tersebut di 
evaluasi berdasarkan kriteria Dobberman dan Fairhurts (2000).

Dari Tabel 3 diketahui Nilai $\mathrm{pH}$ terendah terdapat pada sampel 20 dan 16 yaitu 4.5 dan nilai $\mathrm{pH}$ tertinggi terdapat pada sampel 35 yaitu 4.8. Menurut Staf Pusat Penelitian Tanah (1983) dapat digolongkan status $\mathrm{pH} \mathrm{H} 2 \mathrm{O}$ tanah pada lahan sawah tadah hujan tersebut masam.

Dari Tabel 4 diketahui nilai Na-dd terendah diketahui terdapat pada sampel 7 yaitu $0.14 \mathrm{me} / 100$ dan nilai Na-dd tertinggi terdapat pada sampel nomor 16 dan 30 yaitu 0.17 me/100. Menurut Staf Pusat Penelitian Tanah (1983) dapat digolongkan status Na-dd tanah pada lahan sawah tadah hujan tersebut rendah.

Dari hasil survey yang dilakukan pada Tabel 3 diketahui Nilai $\mathrm{pH}$ tanah terendah terdapat pada sampel 20 dan 16 yaitu 4.5 dan nilai $\mathrm{pH}$ tertinggi terdapat pada sampel 35 yaitu 4.8. Sementara itu pada Tabel 4 diketahui Nilai Na-dd terendah diketahui terdapat pada sampel 7 yaitu 0.14 me/100 dan nilai Na-dd tertinggi terdapat pada sampel nomor 16 dan 30 yaitu $0.17 \mathrm{me} / 100$. Hal ini

\section{SIMPULAN}

Penyebaran tingkat salinitas pada lahan sawah tadah hujan memiliki dua kriteria yaitu tinggi dengan luasan 625 ha $(83,4 \%)$ dan kriteria agak tinggi dengan luasan 125 ha $(16,6 \%)$. Nilai $\mathrm{pH}$ tanah pada lahan sawah tadah hujan memiliki $\mathrm{pH}$ tanah masam dengan rataan 4.7 dan Nilai Na-dd yang rendah dengan rataan $0,15 \mathrm{me} / 100$, sehingga tanah tersebut dapat diklasifikasikan menjadi tanah Salin.

\section{DAFTAR PUSTAKA}

Boiran. 2004. Proses Degradasi Lingkungan. Pusat Penelitian Lingkungan Hidup. Universitas Darussalam. Nanggroe Aceh Dasrussalam.

Badan Pusat Statistik Sumatera Utara. 2016. Statistik Lahan Sawah di Sumatera Utara.

Dobermann, A., dan Fairhurst T. 2000. Rice Nutrient disorders \& nutrient menunjukkan bahwa tanah lahan sawah tadah hujan memiliki $\mathrm{pH}$ tanah masam dan Nilai Na-dd yang rendah, sehingga tanah tersebut dapat diklasifikasikan menjadi tanah Salin. Hal ini sesuai dengan Follet, dkk. (1981) yang menyatakan bahwa, mengklasifikasikan tanah menurut salinitas atas tiga kelompok berdasarkan hasil pengukuran daya hantar listrik sebagai berikut : 1). Tanah salin dengan daya hantar listrik $>4,0$ mmhos/cm, $\mathrm{pH}<8,5$ dan Na-dd $<15 \%$ dengan kondisi fisik normal. Kandungan garam larutan dalam tanah dapat menghambat perkecambahan, penyerapan unsur hara dan pertumbuhan tanaman. 2). Tanah sodik dengan daya hantar listrik < 4,0 mmhos/cm, $\mathrm{pH}>8,5$ dan $\mathrm{Na}$-dd $>15 \%$ dengan kondisi fisik buruk. Garam yang terlarut dalam tanah relatif rendah dan keadaan tanah cenderung terdispersi dan tidak permeabel terhadap air hujan dan air irigasi. 3). Tanah salin sodik dengan daya hantar listrik > 4,0 mmhos/cm, $\mathrm{pH}<8,5$ dan Na-dd $>15 \%$ dengan kondisi fisik normal. Keadaan tanah umumnya terdispersi dengan permeabilitas rendah dan sering tergenang jika diairi.

managemen. Handbook series. Potash \& Phospate Institude of Canada (PPIC) dan International Rice Research Institude. Hal 149152.

Follet, R. H., L. S Murphy, and R. L Donahue, 1981. Fertilizers and Soil Amandments. Prentice-Hall, Inc. Englewood Cliffs, New Jersey.

Hutajulu. H. F., Rosmayati., Syafruddin Ilyas. 2013. Pengujian Respon Pertumbuhan Beberapa Varietas Padi Sawah (Oryza sativa L.) Akibat Cekaman Salinitas. Jurnal Online Agroteknologi. Vol 1. Program Studi Agroekoteknologi. Fakultas Pertanian USU. Medan

Pusat Data dan Sistem Informasi Pertanian. 2016. Outlook Komoditas Pertanian Subsektor Tanaman Pangan. Kementrian Pertanian.

Sembiring, H. dan Gani. A. 2010. Adaptasi Varietas Padi Pada Tanah Terkena 
Tsunami. Balai Besar Penelitian Tanaman Padi, Jakarta.

Staf Pusat Penelitian Tanah, 1983. Jenis Dan Macam Tanah Di Indonesia Untuk Keperluan Survei Dan Pemetaan Tanah Transmigrasi. Pusat Penelitian dan Agroklimat. Bogor.

Subagyono, K., 2008. Kerusakan Lahan Pertanian Akibat Tsunami.. Balai Penelitian Tanah, Bogor.

Susanto, R.H., Budi Rahardjo; dan Rahmad Hari Purnama, 1997. Alternatif Pengelolaan Air dan Pola Tanam di Lahan Usahatani Daerah Rawa Pasang Surut Telang dan Saleh Sumatera Selatan. Prosiding Seminar Peranan Teknologi dalam Meningkatkan Nilai Tambah Komoditas. Jurusan Teknologi Pertanian Fakultas Pertanian. Universitas Sriwijaya. Indralaya. 